\title{
Thigmomorphogenetic responses of an aquatic macrophyte to hydrodynamic stress
}

\author{
Jonas Schoelynck ${ }^{1}{ }^{*}$, Sara Puijalon ${ }^{2}$, Patrick Meire ${ }^{1}$ and Eric Struyf ${ }^{1}$ \\ Ecosystem Management Research Group, Department of Biology, University of Antwerp, Wilrijk, Belgium \\ 2 UMR CNRS 5023 Laboratoire d'Ecologie des Hydrosystèmes Naturels et Anthropisés, Université Lyon 1, Villeurbanne, France
}

\author{
Edited by: \\ Stephen J. Mitchell, University of \\ British Columbia, Canada \\ Reviewed by: \\ Rui Shi, North Carolina State \\ University, USA \\ Klaus Harter, University of \\ Tuebingen, Germany \\ *Correspondence: \\ Jonas Schoelynck, Ecosystem \\ Management Research Group, \\ Department of Biology, University \\ of Antwerp, Universiteitsplein 1, \\ 2610 Wilrijk, Belgium \\ e-mail: jonas.schoelynck@ \\ uantwerpen.be
}

The response of aquatic plants to abiotic factors is a crucial study topic, because the diversity of aquatic vegetation is strongly related to specific adaptations to a variety of environments. This biodiversity ensures resilience of aquatic communities to new and changing ecological conditions. In running water, hydrodynamic disturbance is one of the key factors in this context. While plant adaptations to resource stress (nutrients, light...) are well documented, adaptations to mechanical stress, particularly flow, are largely unknown. The submerged species Egeria densa was used in an experiment to detect whether the presence or absence of hydrodynamic stress causes plant thigmomorphogenetic responses (i) in terms of plant biogenic silica (BSi), cellulose and lignin concentrations, and (ii) in terms of plant strength. Plant silica concentrations, as well as lignin concentrations were significantly higher in presence of hydrodynamic stress. These physiological changes are accompanied by some significant changes in stem biomechanical traits: stem resistance to tensile forces (breaking force and breaking strength) and stiffness were higher for plants exposed to hydrodynamic stress. We conclude that the response of this aquatic plant species to mechanical stress is likely the explaining factor for a higher capacity to tolerate stress through the production of mechanically hardened shoots.

Keywords: silica, lignin, cellulose, Egeria densa, tensile strength, bending strength, Young's modulus

\section{INTRODUCTION}

Aquatic plants can be exposed to important external mechanical forces resulting from pressure exerted by water movement, particularly in flowing ecosystems such as rivers and streams (Puijalon et al., 2011; Puijalon and Bornette, 2013). The consequences for the plants depend on the magnitude of these hydrodynamic forces and on the plants' capacity to resist to the effect of these forces (Schutten et al., 2005; Puijalon et al., 2011). Shoot breakage occurs when the forces encountered by plants exceed their capacity to resist breakage (i.e., breaking force; Vogel, 2003; Schutten et al., 2005). Plants' ability to tolerate water movement without suffering mechanical damage relies either on minimizing the hydrodynamic forces or maximizing its resistance to breakage. When growing under permanent flow conditions, aquatic plants may present important thigmomorphogenetic responses (i.e., developmental responses to external mechanical stimulation; Braam, 2005; Telewski, 2006), which can increase the plant capacity to tolerate hydrodynamic forces. These thigmomorphogenetic responses involve many morphological traits (e.g., reduced plant mass and height, reduced leaf sizes, higher biomass allocation to below-ground organs; Doyle, 2001; Strand and Weisner, 2001), sometimes resulting in extremely modified morphologies such as dwarfed individuals (Puijalon and Bornette, 2013). Studies have demonstrated that these thigmomorphogenetic responses have an adaptive value, reducing the hydrodynamic forces encountered by aquatic plants (Puijalon et al., 2005, 2008), but consequences of these responses for resistance to breakage have rarely been assessed. The resistance to breakage of a plant stem depends on its cross-sectional area and its material strength (Denny, 1988; Niklas, 1992; Vogel, 2003), linked to the proportion of strengthening tissues (Ennos, 1997; Read and Stokes, 2006; Telewski, 2006). Both stem cross-sectional area and proportion of strengthening tissues may be affected by thigmomorphogenetic responses (Bociag et al., 2009), but the actual consequences for aquatic plant resistance to breakage still needs to be investigated.

The strengthening tissue in plants consists mainly of cellulose, which is the majority of plant cell wall material. In the intercellular space, lignin can be incorporated to provide additional rigidity and compressive strength to cell walls. It also renders the cell wall hydrophobic and impermeable to water (Turner et al., 2001). Cellulose is a relatively pure compound of glucose units (i.e., polysaccharides). Lignin, however, does not have a unique chemical formula, but is a complex molecule composed of repeating phenylpropane units composed of an aromatic ring with three carbon side-chains. The phenolic groups vary between plants, further confounding the definition of lignin (Palm and Rowland, 1997). Fundamental physiological research on how these components give strength to plants is mainly restricted to (parts of) terrestrial vegetation. During tree growth, for example, cellulose microfibrils give cell walls tensile strength (Sjostrom, 
1993), and lignin encasing the cellulose microfibrils imparts rigidity to cell walls (Hu et al., 1999; Genet et al., 2005). For nonwoody species, Carpita et al. (2001) state that it is likely that $15 \%$ of the Arabidopsis genome is dedicated to cell wall biogenesis and modification, which allows the cell to resist the gravitational forces and/or tensile forces associated with the transpirational pull on a column of water. Turner et al. (2001) showed that mutation of Arabidopsis, rendering it incapable of secondary cell wall synthesis, causes the cells to collapse. Additionally, cell wall analysis in barley mutants revealed that the maximum bending stress correlated significantly with the cellulose content but not with lignin. Generally, according to Kaufman et al. (1999), the use of lignin diminishes flexibility. The pathways for cellulose and lignin biosynthesis must thus be regulated in a highly coordinated manner, to achieve the proper deposition of these polymers during secondary wall formation. How this co-ordination is achieved remains largely unclear (Turner et al., 2001).

Apart from strength provided by lignin and cellulose, biogenic silica (BSi) can also provide support to the shoot (Kaufman et al., 1999) by giving structural rigidity to the cell wall (Green et al., 1975 ) at a 10- to 20-fold lower cost (Raven, 1983). Silica is an energetically cheap stiffening material, promoting upright stature and resistance to lodging (flattening by wind or rain). A first relation between silica, cellulose and lignin for aquatic vegetation was shown by Schoelynck et al. (2010). These authors found interspecific relations between silica and cellulose and antagonistic relations between silica and lignin. Relations could be positive or negative, depending on the growth form of the species (submerged versus emerged). Later, Schoelynck et al. (2012) showed that these relations could hold up intraspecifically in the stems of a single submerged aquatic species (Nuphar lutea L.): more silica is associated with less cellulose and with more lignin. This study also demonstrated that, in absence of hydrodynamic stress, Si in the biomass of Egeria densa Planch. was positively logarithmically related to increasing ambient $\mathrm{Si}$ concentrations, until apparent saturation is reached, beyond which biomass Si concentration stabilized. Next it was demonstrated that exposure to hydrodynamic stress could induce higher Si concentrations in stem and leaf tissue of E. densa and Limnophila heterophylla (Roxb.) Benth. under experimental conditions and in the tissue of N. lutea under natural conditions. The authors however, demonstrated neither the direct effect of hydrodynamic stress on cellulose and lignin production nor the consequences of the changes in silica, cellulose and lignin induced by hydrodynamic stress on the plants' resistance to this stress (i.e., the plants' strength).

In this study, we experimentally tested whether $\mathrm{Si}$ is involved in plant thigmomorphogenetic adaptations to mechanical perturbation, resulting in higher mechanical resistance. It is hypothesized that in case of mechanical perturbation, the plants take up $\mathrm{Si}$, resulting in higher mechanical resistance due to the association of $\mathrm{Si}$ with cellulose and lignin.

\section{MATERIALS AND METHODS EXPERIMENTAL SETUP}

Two aquaria $(110 \mathrm{~L})$ were filled with tap water (nutrient concentration: $3.65 \pm 0.25 \mathrm{mg} \mathrm{L}^{-1} \quad \mathrm{NO}_{3}{ }^{-}$and $0.15 \pm$ $\left.0.04 \mathrm{mg} \mathrm{L}^{-1} \mathrm{PO}_{4}{ }^{3-} ; \mathrm{pH}: 8.4\right)$. Dissolved silicon concentration was set at $5.0 \pm 0.4 \mathrm{mg} \mathrm{Si} \mathrm{L} \mathrm{L}^{-1}$ by adding silicic acid $\left(\mathrm{SiO}_{2}{ }^{*} \mathrm{xH}_{2} \mathrm{O}\right.$; Merck, Darmstadt, Germany, DAB certificated). This concentration is on the lower end of what is commonly found in lowland rivers and streams (Struyf et al., 2010). Silica concentrations were carefully monitored by analysis on an ICP-OES spectrometer (iCAP 6000 series, Thermo Scientific, Cambridge, UK) to maintain equal concentrations in both aquaria, with $\mathrm{SiO}_{2}$ added when necessary. Nutrient availability was regularly monitored by analysis on a colorimetric segmented flow analyzer $\left(\mathrm{SAN}^{++}\right.$, Skalar, Breda, Netherlands) but did not change significantly during the course of the experiment. In the first aquarium, hydrodynamic stress was created by installing a rotor (Turbelle Stream, Tunze, Penzberg, Germany) in the top one-third of the water column. This rotor created a highly turbulent flow regime with a top speed of $0.5 \pm 0.1 \mathrm{~m} \mathrm{~s}^{-1}$ around the plants. This pushed the plants mainly in the downstream direction, but because of the turbulence, they were moving constantly (as in a natural situation). The water was also aerated with a regular air stone. In the second aquarium, the water was almost static as a regular air stone created only little water movement, minimizing boundary layers around the shoots. In each aquarium, 100 mature shoots of the submerged macrophyte Egeria densa Planch. (non-commelinoid monocots) were added in 10 groups of 10 individuals each. An extra control group of 10 shoots was kept apart to determine original stem morphological traits (length, diameter and fresh mass) before the experiment. The plants were bought at a plant nursery shop where they were grown in tap water under optimal conditions. The experiment ran for 21 days in a climate chamber at a constant temperature $\left(20^{\circ} \mathrm{C}\right)$ and a day-night regime of $14 \mathrm{~h}$ light (PAR: $50 \mu \mathrm{mol} \mathrm{m}^{-2} \mathrm{~s}^{-1}$ ).

\section{MEASUREMENTS OF BIOMECHANICAL TRAITS}

All plants were entirely defoliated immediately after the experiment. 30 stems were randomly picked per aquarium (three per group), and total length, diameter, and fresh mass of the stems was determined. The diameter was measured with a digital caliper $( \pm 0.01 \mathrm{~mm})$ at three different points along the $5 \mathrm{~cm}$ basal stem part and averaged per sample. The differences between these data and that of 10 original control stems give an indication of the growth and performance of the plants over the course of the experiment (21 days). Next, the biomechanical properties of this subset of stems from the experiment were measured through (i) bending and (ii) tensile tests using a universal testing machine (Instron 5942, Canton, MA, USA).

\section{Bending tests}

As three-point bending tests could not be performed due to the too high flexibility of the plant stems, the samples were tested as cantilever beams using a one-fixed end bending test (Hamann and Puijalon, 2013). The basal stem samples (5 cm long) were clamped horizontally at their basal end while a force was applied at their midpoint by lowering a probe at a constant rate of $10 \mathrm{~mm} \mathrm{~min}{ }^{-1}$. We calculated the following biomechanical traits related to bending:

- The bending Young's modulus ( $E$ in Pa) quantifies the material stiffness and is calculated as the slope of the stress-strain curve in the elastic deformation region. 
- The second moment of area $\left(I\right.$ in $\left.\mathrm{m}^{4}\right)$ quantifies the distribution of material around the axis of bending, accounting for the effect of the cross-sectional geometry of a structure on its bending stress. As stem cross section was circular, $I$ was calculated as $I=\left(\pi r^{4}\right) / 4$, where $\mathrm{r}$ is the radius of stem cross section (Niklas, 1992).

- The flexural stiffness ( $E I$ in $\mathrm{N} \mathrm{m}^{2}$ ) quantifies the stiffness of the stem fragment, i.e., the extent to which the segment resists deformation in response to an applied force, and was calculated by multiplying $E$ and $I$.

\section{Tensile tests}

The stem fragments (approximately $8 \mathrm{~cm}$ long) were clamped into the jaws of the testing machine and a constant extension rate of $5 \mathrm{~mm} \mathrm{~min}^{-1}$ was applied to the upper jaw until they broke. We calculated the following biomechanical traits at the sample breaking point:

- The breaking force (in N) is defined as the maximum force that the sample can bear without suffering mechanical failure.

- The tensile strength (in $\mathrm{N} \mathrm{m}^{-2}$ ) is calculated as the breaking force per cross-sectional area and quantifies the maximum force that the sample can bear corrected by its cross-sectional area.

- The tensile Young's modulus ( $E$ in $\mathrm{Pa}$ ) is defined as the slope of a sample's stress-strain curve in the elastic deformation region and quantifies the segment stiffness, i.e., the extent to which the segment resists deformation in response to an applied force.

The diameter of all the stem fragments was measured using a digital caliper $( \pm 0.02 \mathrm{~mm})$ at three different points along the sample.

\section{CHEMICAL ANALYSES}

After the strength measurements, the subset of basal stem parts was rejoined with their respective upper parts and all entire 200 shoots were dried at $70^{\circ} \mathrm{C}$ for $48 \mathrm{~h}$. Stems and leaves were kept separated, but individuals were grouped together per original set of ten shoot, resulting in 40 samples (10 leaf samples and 10 stem samples from the aquarium with hydrodynamic stress and similar for the aquarium without stress). This was needed to obtain sufficient dry matter to perform all chemical analyses. Samples were grounded and homogenized with a mill. BSi was then extracted from $25 \mathrm{mg}$ of dry plant material by incubation in a $0.1 \mathrm{M} \mathrm{Na}_{2} \mathrm{CO}_{3}$ mixture at $80^{\circ} \mathrm{C}$ during $5 \mathrm{~h}$ (DeMaster, 1981). The extracted and dissolved silica was analyzed on a colorimetric segmented flow analyser $\left(\mathrm{SAN}^{++}\right.$, Skalar, Breda, The Netherlands). The extraction in $0.1 \mathrm{M} \mathrm{Na}_{2} \mathrm{CO}_{3}$ at $80^{\circ}$ has been well established and tested: it is capable of fully dissolving the BSi from plant phytoliths at the solid-solution ratios and extraction time we applied (Saccone et al., 2007). For lignin analysis, basically two major techniques are often used: "Klason lignin" determination for forestry products (Effland, 1977) and "ADF-lignin" for assessing animal forage quality (Van Soest, 1963). The latter is often referred to as more precise and more reproducible (Ryan et al., 1990; Rowland and Roberts, 1994). Moreover, the Van Soest (1963) method also enables to determine $\alpha$-cellulose separately from hemicellulose, in contrast to the Effland (1977) method. We used the Van Soest (1963) method to analyze the plant samples for $\alpha$-cellulose and ADF-lignin. In short, between 0.5 and $1 \mathrm{~g}$ of dry plant material was treated with cetyl-trimethylammoniumbromide to dissolve and remove proteins. The remaining material was treated with a $72 \%$ sulphuric acid. After weighing and drying $\left(105^{\circ} \mathrm{C}\right)$, the $\alpha$-cellulose content is calculated by subtracting the mass before and after the sulphuric acid treatment and dividing this value by the initial material mass. In a third step the remaining material was ignited at $550^{\circ} \mathrm{C}$ : the $\mathrm{ADF}$ lignin content was then calculated by subtracting the mass before and after ignition and dividing it by the initial material mass. We will further refer to ADF-lignin and $\alpha$-cellulose as lignin and cellulose.

\section{STATISTICS}

Per aquarium, the 30 biomechanical traits analyses on stems and 20 chemical analyses on stems and leaves were averaged and a standard deviation was calculated. We used a Shapiro-Wilk normality test and a Bartlett test of homogeneity of variances on all datasets. Depending whether the assumptions were met or not, we used a $t$-test test or Kruskal-Wallis chi-squared test respectively.

\section{RESULTS}

All plants survived both treatments and performed well (Table 1). There was no significant difference in the length of the mature shoots between the two treatments $\left(t_{204}=0.73, p=0.46, t\right.$-test $)$ and between the control and treatment plants $\left(t_{56}=-1.13\right.$, $p=0.26, t$-test control $\times$ stress and $t_{70}=-1.62, p=0.11$, $t$-test control $\times$ no stress). This implies no length growth (growth rate $\left.=0 \mathrm{~cm} \mathrm{day}^{-1}\right)$. The experimental stems did increase significantly in diameter as compared to the controls $\left(t_{13}=-8.29\right.$, $p<0.001, t$-test control $\times$ stress and $t_{19}=-9.67, p<0.001$, $t$-test control $\times$ no stress), but did not differ significantly between the two treatments $\left(t_{38}=-3.38, p>0.05, t\right.$-test $)$. This implies a diameter increase of $0.05 \mathrm{~mm} \mathrm{day}^{-1}$. The experimental stems did also increase significantly in fresh mass as compared to the controls $\left(t_{90}=-5.87, p<0.001, t\right.$-test control $\times$ stress and $t_{94}=-8.75, p<0.001, t$-test control $\times$ no stress $)$, but did not differ significantly between the two treatments $\left(t_{13}=-8.29\right.$, $p>0.05, t$-test). This implies a mass increase of $50 \mathrm{mg} \mathrm{day}^{-1}$.

\section{CHEMICAL TRAITS}

Silica concentration was always higher in leaves than in stems. Individuals that were exposed to hydrodynamic stress had significantly higher Si concentrations in both leaves and stems, as compared to individuals not exposed to stress (Figure 1A;

Table 1 | Stem morphological traits (length, diameter, and fresh mass).

\begin{tabular}{lccc}
\hline & Control & No stress & Stress \\
\hline Length $(\mathrm{cm})$ & $23.6 \pm 4.0^{\mathrm{a}}$ & $25.0 \pm 5.4^{\mathrm{a}}$ & $24.5 \pm 4.2^{\mathrm{a}}$ \\
Diameter $(\mathrm{mm})$ & $1.05 \pm 0.23^{\mathrm{a}}$ & $1.94 \pm 0.27^{\mathrm{b}}$ & $1.72 \pm 0.16^{\mathrm{b}}$ \\
Fresh mass $(\mathrm{g})$ & $2.06 \pm 0.59^{\mathrm{a}}$ & $3.31 \pm 1.04^{\mathrm{b}}$ & $2.90 \pm 0.97^{\mathrm{b}}$
\end{tabular}

Characters in superscript reflect the significant differences between treatments (control, no stress, stress) for each morphological trait, $p<0.05$. 

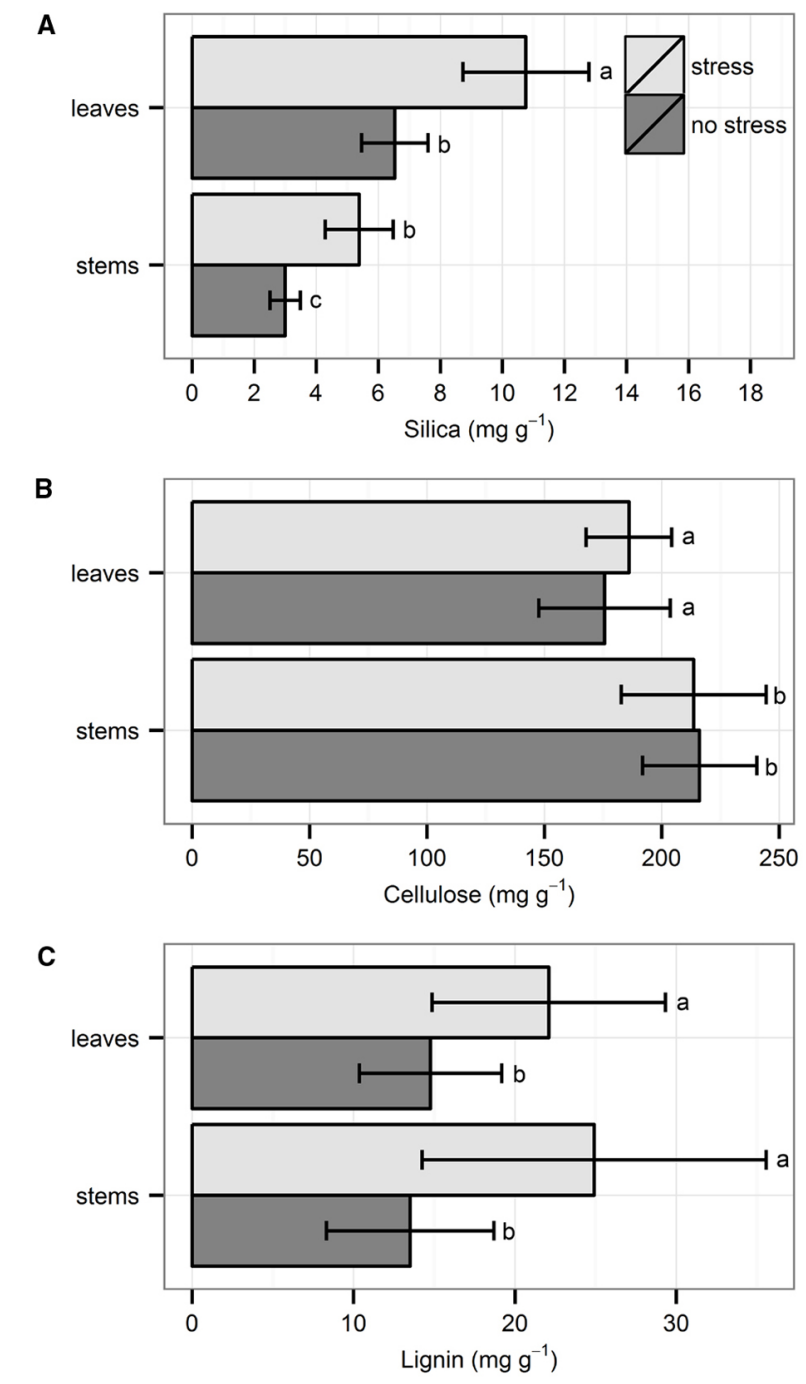

FIGURE 1 | Chemical properties of the leaves and shoots: (A) silica, (B) cellulose, and (C) lignin. Data are averages with standard deviation $(n=10)$. Character symbols reflect the significant differences between treatments (stress, no stress) for each plant organ (leaves, stems) and between each plant organ; $p<0.05$.

$\chi^{2}{ }_{1}=13.72, p<0.001$, Kruskal-Wallis test). Cellulose concentration was always higher in stems than in leaves, but there was no significant difference between the two treatments (Figure 1B; $t_{18}=0.20, p=0.84, t$-test). There was no difference in lignin concentration between stems and leaves, but the concentration was always significantly higher under stressful conditions in both organs (Figure 1C; $\chi^{2}{ }_{1}=8.17, p<0.01$, Kruskal-Wallis test).

\section{BIOMECHANICAL TRAITS}

The three biomechanical traits measured through tensile tests were significantly higher for plants exposed to hydrodynamic stress (Figure 2): breaking force $\left(\chi^{2}{ }_{1}=4.76, p=0.03\right.$, KruskalWallis test $)$, tensile strength $\left(\chi^{2}{ }_{1}=4.26, p=0.04\right.$, Kruskal-Wallis test) and tensile Young's modulus $\left(\chi^{2}{ }_{1}=4.28, p=0.04\right.$, KruskalWallis test).

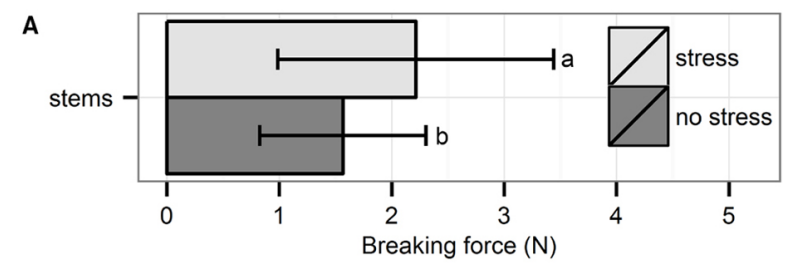

B

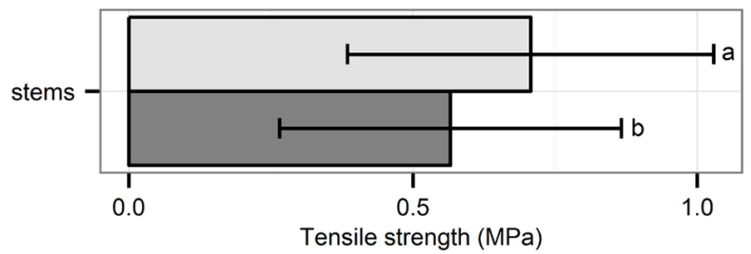

C

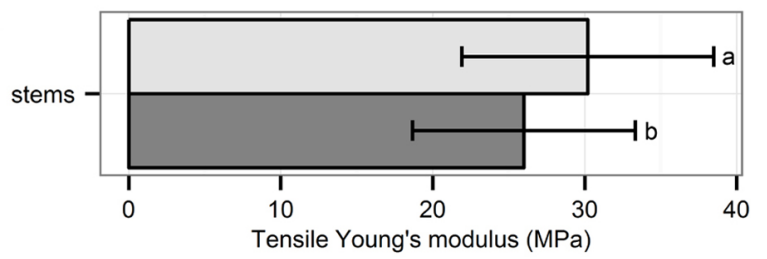

FIGURE 2 | Biomechanical properties of the stems measured through tensile test: $(A)$ breaking force, $(B)$ tensile strength, and $(C)$ tensile Young's modulus. Data are averages with standard deviation $(n=30)$. Character symbols reflect the significant differences between treatments (stress, no stress); $p<0.05$.
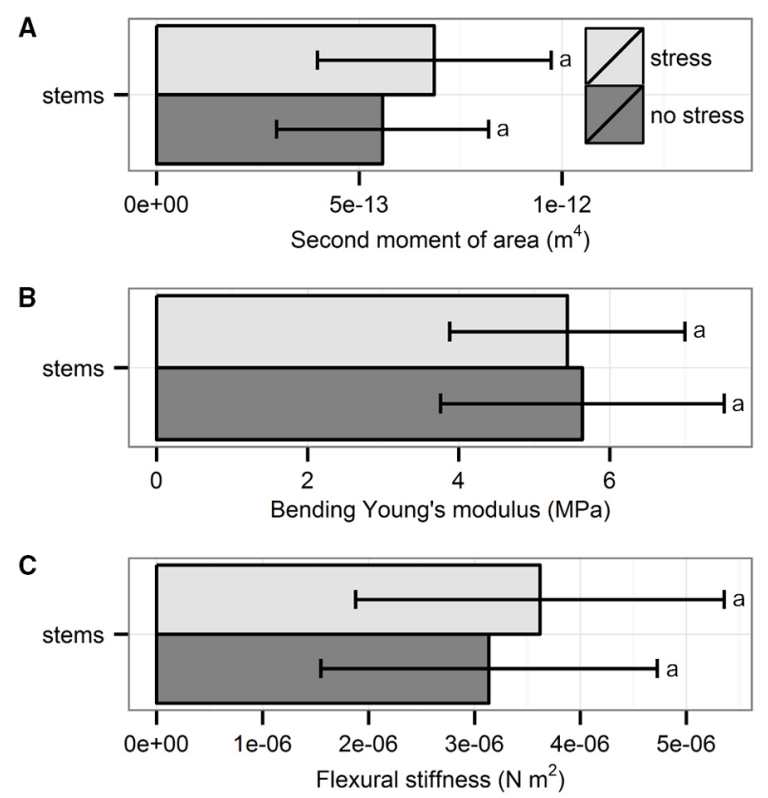

FIGURE 3 | Biomechanical properties of the stems measured through bending tests: (A) second moment of area, (B) bending Young's modulus, and (C) flexural stiffness. Data are averages with standard deviation $(n=30)$. No significant differences were found; $p>0.05$.

The three biomechanical traits measured through bending tests did not differ significantly between plants from the two treatments (Figure 3): second moment of area $\left(t_{56}=1.76, p=0.08\right.$, 
$t$-test), Young's modulus $\left(t_{54}=-0.44, p=0.66, t\right.$-test $)$ and flexural stiffness $\left(\chi^{2}{ }_{1}=1.07, p=0.30\right.$, Kruskal-Wallis test $)$

\section{DISCUSSION}

In accordance with our hypothesis, the results demonstrate that some biomechanical traits of Egeria densa were significantly affected by mechanical stimulation: exposure to hydrodynamic stress led to higher resistance to tensile forces (higher breaking force and tensile strength) and higher stiffness in tension, but did not modify the biomechanical traits in bending. Due to their high flexibility, the shoots of submerged aquatic plants exposed to flow generally align in the flow direction, and are consequently mostly subjected to tensile forces induced by hydrodynamic forces (Usherwood et al., 1997; Schutten and Davy, 2000; Puijalon et al., 2011). A high breaking force and tensile strength represents thus an important adaptation to flowing waters, reducing the risk for the plants to suffer mechanical failure of their shoots (Usherwood et al., 1997; Puijalon et al., 2011; Miler et al., 2012). The thigmomorphogenetic response to hydrodynamic stress observed in the present study may thus have an important adaptive value in increasing the capacity of the plants to tolerate the stress encountered through the production of a mechanically hardened phenotype. The response time is also rather fast as the experiment lasted for only 21 days. The present study demonstrates that the aquatic plants can adapt relatively quick to longer periods of hydrodynamic stress (order of weeks) not only through the production of a phenotype reducing the hydrodynamic forces (Puijalon et al., 2005, 2008), but also through the production of phenotypes increasing the mechanical resistance (i.e., higher resistance to breakage). Adaptation to mechanical stress through production of morphologies mechanically more resistant has been demonstrated for a long time on terrestrial plant species exposed to wind (e.g., Jaffe et al., 1984; Telewski and Jaffe, 1986), on marine algae exposed to waves (e.g., Biedka et al., 1987; Anderson et al., 2006), but not on aquatic plants (Bociag et al., 2009).

This research also confirms the earlier relation between lignin and biogenic Si deposition observed in submerged macrophytes (Schoelynck et al., 2010), and the observed silica uptake by macrophytes in response to hydrodynamical stress (Schoelynck et al., 2012). Emerging research links lignification and biogenic Si metabolism (Ghasemi et al., 2013; Zhang et al., 2013). It has been suggested that lignin can act as a precursor for biogenic Si deposition (Zhang et al., 2013), but the actual physiological mechanisms are currently not known. Although research is also still limited, more evidence points towards silica deposition being closely related to cellulose biosynthesis too. It was found that silica is present in beech leaves as precipitates in the walls of the epidermal and parenchymatous cells, either in the middle lamellae or in the cells against the walls or in the cell intersections (Watteau and Villemin, 2001). In this case, BSi and cellulose, hemicellulose and pectic substances are closely associated (Watteau and Villemin, 2001). Later, Shobbar et al. (2008) found that plants have evolved a broad protective mechanism linking the health and growth of the secondary cell wall with resistance to abiotic and biotic stresses, and abscisic acid (ABA) is the mediator of the mechanism. In times of stress, $\mathrm{ABA}$ induces transcripts that encode for cellulose synthase and, at the same time, these transcripts appear in so-called silica cells. These silica containing cells are equally important for leaf strength as is the cell wall. In a recent paper, Fraysse et al. (2010) support the hypothesis of the existence of individual molecules $\mathrm{H}_{4} \mathrm{SiO}_{4}$ or small polymers (silica gel, $\mathrm{SiO}_{2} \cdot \mathrm{nH}_{2} \mathrm{O}$ ) dispersed in the organic matrix of the cell wall.

The inclusion of $\mathrm{Si}$ uptake as a plant functional trait is important to assess links between plant physiology, plant distribution and plant tolerance to environmental changes, but also to understand the role of vegetation on nutrient fluxes through the watershed (Schoelynck et al., 2014b). There is a growing line of evidence that Si uptake in wetland and aquatic macrophytes has important implications for other biogeochemical cycles. In a recent study, Si content of aquatic macrophytes increased decomposition rate of the litter, even under low quality conditions with a low C/N ratio (Schaller and Struyf, 2013). Interestingly, when shredders were present, Si had an adverse impact on the decomposition rate. Si uptake in aquatic macrophytes has further also been linked to concentrations of both macro- and micronutrients (Schaller et al., 2012; Schaller and Struyf, 2013), with, e.g., CNP ratios altered by $\mathrm{Si}$ deposition and reduced uptake of metals. If plants thus adapt to alterations in hydrological conditions, e.g., induced by more frequent occurrence of peak floods after drainage basin build-up or due to increased occurrence of storm rains, this could alter their impact on other biogeochemical cycles. Aquatic macrophytes are known to create biogeochemical hotspots in their growth patches compared to adjacent nonvegetated areas, with increased organic matter storage and nutrient cycling observed in the patches (Sand-Jensen, 1998; Cotton et al., 2006; Kleeberg et al., 2010; Schoelynck et al., 2014a). Interestingly, the engineering capacity of macrophyte patches to trap and store organic matter is itself to a great extent determined by the rigidity of the stems (Gurnell, 2014).

\section{CONCLUSION}

We conclude that the presence of hydrodynamic stress triggers the uptake of silica in Egeria densa, which is linked to changes in the lignin concentration. These responses to mechanical stress are likely the explaining factor for a higher capacity to tolerate this stress through the production of mechanically hardened shoots. These thigmomorphogenetic responses can help to improve the survival chances of the species.

\section{ACKNOWLEDGMENTS}

We would like to thank Ruby Neervoort and Marie-Rose Viricel for helping with the experiments. This research was executed with the financial support of the Tournesol framework 2013 and 2014: The role of biogenic silica in macrophyte resistance to hydrodynamic stress (project $n^{\circ}$ T2013.23 and $n^{\circ} 28897 Q G$ ), and also partly of FWO Flanders for the Scientific Research Network (WOG) "the functioning of river ecosystems through plant-flowsoil interactions" (W0.027.11N).

\section{REFERENCES}

Anderson, K., Close, L., Dewreede, R. E., Lynch, B. J., Ormond, C., and Walker, M. (2006). Biomechanical properties and holdfast morphology of coenocytic algae (Halimedales, Chlorophyta) in Bocas del Toro, Panama. J. Exp. Mar. Biol. Ecol. 328, 155-167. doi: 10.1016/j.jembe.2005.07.005 
Biedka, R. F., Gosline, J. M., and Dewreede, R. E. (1987). Biomechanical analysis of wave-induced mortality in the marine alga Pterygophora californica. Mar. Ecol. Prog. Ser. 36, 163-170. doi: 10.3354/meps036163

Bociag, K., Galka, A., Lazarewicz, T., and Szmeja, J. (2009). Mechanical strength of stems in aquatic macrophytes. Acta Soc. Bot. Pol. 78, 181-187. doi: 10.5586/ asbp.2009.022

Braam, J. (2005). In touch: plant responses to mechanical stimuli. New Phytol. 165, 373-389. doi: 10.1111/j.1469-8137.2004.01263.x

Carpita, N., Tierney, M., and Campbell, M. (2001). Molecular biology of the plant cell wall: searching for the genes that define structure, architecture and dynamics. Plant Mol. Biol. 47, 1-5. doi: 10.1023/A:1010603527077

Cotton, J. A., Wharton, G., Bass, J. A. B., Heppell, C. M., and Wotton, R. S. (2006). The effects of seasonal changes to in-stream vegetation cover on patterns of flow and accumulation of sediment. Geomorphology 77, 320-334. doi: 10.1016/ j.geomorph.2006.01.010

DeMaster, D. J. (1981). The supply and accumulation of silica in the marineenvironment. Geochim. Cosmochim. Acta 45, 1715-1732. doi: 10.1016/00167037(81)90006-5

Denny, M. (1988). Biology and the Mechanics of the Wave-Swept Environment. Princeton, NJ: Princeton University Press.

Doyle, R. D. (2001). Effects of waves on the early growth of Vallisneria americana. Freshw. Biol. 46, 389-397. doi: 10.1046/j.1365-2427.2001.00668.x

Effland, M. J. (1977). Modified procedure to determine insoluble lignin in wood and pulp. Tappi 60, 143-144.

Ennos, A. R. (1997). Wind as an ecological factor. Trends Ecol. Evol. 12, 108-111. doi: 10.1016/s0169-5347(96)10066-5

Fraysse, F., Pokrovsky, O. S., and Meunier, J. D. (2010). Experimental study of terrestrial plant litter interaction with aqueous solutions. Geochim. Cosmochim. Acta 74, 70-84. doi: 10.1016/j.gca.2009.09.002

Genet, M., Stokes, A., Salin, F., Mickovski, S. B., Fourcaud, T., Dumail, J. F., et al. (2005). The influence of cellulose content on tensile strength in tree roots. Plant Soil 278, 1-9. doi: 10.1007/s11104-005-8768-6

Ghasemi, E., Ghorbani, G. R., Khorvash, M., Emami, M. R., and Karimi, K. (2013). Chemical composition, cell wall features and degradability of stem, leaf blade and sheath in untreated and alkali-treated rice straw. Animal 7, 1106-1112. doi: $10.1017 / \mathrm{s} 1751731113000256$

Green, N. E., Hadwiger, L. A., and Graham, S. O. (1975). Phenylalanine ammonialyase, tyrosine ammonia-lyase, and lignin in weat inoculated with Erysiphe graminis f-sp Tritici. Phytopathology 65, 1071-1074. doi: 10.1094/Phyto-651071

Gurnell, A. M. (2014). Plants as river system engineers. Earth Surf. Proc. Landforms 39, 4-25. doi: 10.1002/esp.3397

Hamann, E., and Puijalon, S. (2013). Biomechanical responses of aquatic plants to aerial conditions. Ann. Bot. 112, 1869-1878. doi: 10.1093/aob/ mct221

Hu, W. J., Harding, S. A., Lung, J., Popko, J. L., Ralph, J., Stokke, D. D., et al. (1999). Repression of lignin biosynthesis promotes cellulose accumulation and growth in transgenic trees. Nat. Biotechnol. 17, 808-812. doi: 10.1038/ 11758

Jaffe, M. J., Telewski, F. W., and Cooke, P. W. (1984). Thigmomorphogenesis—on the mechanical properties of mechanically perturbed bean plants. Physiol. Plant. 62, 73-78. doi: 10.1111/j.1399-3054.1984.tb05925.x

Kaufman, P. B., Cseke, L. J., Warber, S., Duke, J. A., and Brielman, H. L. (1999). Natural Products from Plants. Boca Raton, FL: CRC Press LCC.

Kleeberg, A., Kohler, J., Sukhodolova, T., and Sukhodolov, A. (2010). Effects of aquatic macrophytes on organic matter deposition, resuspension and phosphorus entrainment in a lowland river. Freshw. Biol. 55, 326-345. doi: 10.1111/j.1365-2427.2009.02277.x

Miler, O., Albayrak, I., Nikora, V., and O'hare, M. (2012). Biomechanical properties of aquatic plants and their effects on plant-flow interactions in streams and rivers. Aquatic Sci. 74, 31-44. doi: 10.1007/s00027-011-0188-5

Niklas, K. J. (1992). Plant Biomechanics: An Engineering Approach to Plant form and Function. Chicago, IL: University of Chicago Press.

Palm, C. A., and Rowland, A. P. (1997). "Chemical characterization of plant quality for decomposition," in Driven by Nature: Plant Litter Quality and Decomposition, eds G. Cadish and K. E. Giller. (Wallingford: CAB International), 379-392.

Puijalon, S., and Bornette, G. (2013). "Ecohydraulics: an integrated approach," in Multi-Scale Macrophyte Responses to Hydrodynamic Stress and Disturbances:
Adaptive Strategies and Biodiversity Patterns, eds I. Maddock, A. Harby, P. Kemp, and P. Wood. (Chichester: John Wiley \& Sons, Ltd.), 462.

Puijalon, S., Bornette, G., and Sagnes, P. (2005). Adaptations to increasing hydraulic stress: morphology, hydrodynamics and fitness of two higher aquatic plant species. J. Exp. Bot. 56, 777-786. doi: 10.1093/jxb/eri063

Puijalon, S., Bouma, T. J., Douady, C. J., Van Groenendael, J., Anten, N. P. R., Martel, E., et al. (2011). Plant resistance to mechanical stress: evidence of an avoidance-tolerance trade-off. New Phytol. 191, 1141-1149. doi: 10.1111/j.14698137.2011.03763.x

Puijalon, S., Lena, J. P., Riviere, N., Champagne, J. Y., Rostan, J. C., and Bornette, G. (2008). Phenotypic plasticity in response to mechanical stress: hydrodynamic performance and fitness of four aquatic plant species. New Phytol. 177, 907-917. doi: 10.1111/j.1469-8137.2007.02314.x

Raven, J. A. (1983). The transport and function of silicon in plants. Biol. Rev. Camb. Philos. Soc. 58, 179-207. doi: 10.1111/j.1469-185X.1983.tb00385.x

Read, J., and Stokes, A. (2006). Plant biomechanics in an ecological context. Am. J. Bot. 93, 1546-1565. doi: 10.3732/ajb.93.10.1546

Rowland, A. P., and Roberts, J. D. (1994). Lignin and cellulose fractionation in decomposition studies using acid-detergent fiber methods. Commun. Soil Sci. Plant Anal. 25, 269-277. doi: 10.1080/00103629409369035

Ryan, M. G., Melillo, J. M., and Ricca, A. (1990). A comparison of methods for determining proximate carbon fractions of forest litter. Can. J. For. Res. 20, 166171. doi: $10.1139 / \times 90-023$

Saccone, L., Conley, D. J., Koning, E., Sauer, D., Sommer, M., Kaczorek, D., et al. (2007). Assessing the extraction and quantification of amorphous silica in soils of forest and grassland ecosystems. Eur. J. Soil Sci. 58, 1446-1459. doi: 10.1111/j.1365-2389.2007.00949.x

Sand-Jensen, K. (1998). Influence of submerged macrophytes on sediment composition and near-bed flow in lowland streams. Freshw. Biol. 39, 663-679. doi: 10.1046/j.1365-2427.1998.00316.x

Schaller, J., Brackhage, C., Gessner, M. O., Baüker, E., and Dudel, E. G. (2012). Silicon supply modifies C:N:P stoichiometry and growth of Phragmites australis. Plant Biol. 14, 392-396. doi: 10.1111/j.1438-8677.2011. 00537.x

Schaller, J., and Struyf, E. (2013). Silicon controls microbial decay and nutrient release of grass litter during aquatic decomposition. Hydrobiologia 709, 201212. doi: 10.1007/s10750-013-1449-1

Schoelynck, J., Bal, K., Backx, H., Okruszko, T., Meire, P., and Struyf, S. (2010). Silica uptake in aquatic and wetland macrophytes: a strategic choice between silica, lignin and cellulose? New Phytol. 186, 385-391. doi: 10.1111/j.14698137.2009.03176.x

Schoelynck, J., Bal, K., Puijalon, S., Meire, P., and Struyf, E. (2012). Hydrodynamically mediated macrophyte Si dynamics. Plant Biol. 14, 997-1005. doi: 10.1111/j.1438-8677.2012.00583.x

Schoelynck, J., Bal, K., Verschoren, V., Penning, E., Struyf, E., Bouma, T., et al. (2014a). Different morphology of Nuphar lutea in two contrasting aquatic environments and its effect on ecosystem engineering. Earth Surf. Proc. Landforms 39, 2100-2108. doi: 10.1002/esp.3607

Schoelynck, J., Müller, F., Vandevenne, F., Bal, K., Barao, L., Smis, A., et al. (2014b). Silicon-vegetation interaction in multiple ecosystems: a review. J. Veg. Sci. 25, 301-313. doi: 10.1111/jvs. 12055

Schutten, J., Dainty, J., and Davy, A. J. (2005). Root anchorage and its significance for submerged plants in shallow lakes. J. Ecol. 93, 556-571. doi: 10.1111/j.13652745.2005.00980.x

Schutten, J., and Davy, A. J. (2000). Predicting the hydraulic forces on submerged macrophytes from current velocity, biomass and morphology. Oecologia 123, 445-452. doi: 10.1007/s004420000348

Shobbar, Z. S., Oane, R., Gamuyao, R., De Palma, J., Malboobi, M. A., Karimzadeh, G., et al. (2008). Abscisic acid regulates gene expression in cortical fiber cells and silica cells of rice shoots. New Phytol. 178, 68-79. doi: 10.1111/j.14698137.2007.02365. $\mathrm{x}$

Sjostrom, E. (1993). Wood Chemistry Fundamentals and Applications. San Diego: Academic Press Inc.

Strand, J. A., and Weisner, S. E. B. (2001). Morphological plastic responses to water depth and wave exposure in an aquatic plant (Myriophyllum spicatum). J. Ecol. 89, 166-175. doi: 10.1046/j.1365-2745.2001.00530.x

Struyf, E., Smis, A., Van Damme, S., Garnier, J., Govers, G., Van Wesemael, B., et al. (2010). Historical land use change has lowered terrestrial silica mobilization. Nat. Commun. 1:129. doi: 10.1038/ncomms1128 
Telewski, F. W. (2006). A unified hypothesis of mechanoperception in plants. Am. J. Bot. 93, 1466-1476. doi: 10.3732/ajb.93.10.1466

Telewski, F. W., and Jaffe, M. J. (1986). Thigmomorphogenesis-field and laboratory studies of Abies fraseri in response to wind or mechanical perturbation. Physiol. Plant. 66, 211-218. doi: 10.1111/j.1399-3054.1986.tb02411.x

Turner, S. R., Taylor, N., and Jones, L. (2001). Mutations of the secondary cell wall. Plant Mol. Biol. 47, 209-219. doi: 10.1023/A:1010695818416

Usherwood, J. R., Ennos, A. R., and Ball, D. J. (1997). Mechanical and anatomical adaptations in terrestrial and aquatic buttercups to their respective environments. J. Exp. Bot. 48, 1469-1475. doi: 10.1093/jxb/48.7.1469

Van Soest, P. J. (1963). Use of detergents in analysis of fibrous feeds.II. a rapid method for determination of fiber and lignin. J. Assoc. Off. Agric. Chem. 46, $829-835$.

Vogel, S. (2003). Comparative Biomechanics: Life's Physical World. New Jersey: Princeton University Press.

Watteau, F., and Villemin, G. (2001). Ultrastructural study of the biogeochemical cycle of silicon in the soil and litter of a temperate forest. Eur. J. Soil Sci. 52, 385-396. doi: 10.1046/j.1365-2389.2001.00391.x

Zhang, C. C., Wang, L. J., Zhang, W. X., and Zhang, F. S. (2013). Do lignification and silicification of the cell wall precede silicon deposition in the silica cell of the rice (Oryza sativa L.) leaf epidermis? Plant Soil 372, 137-149. doi: 10.1007/ s11104-013-1723-z

Conflict of Interest Statement: The authors declare that the research was conducted in the absence of any commercial or financial relationships that could be construed as a potential conflict of interest.

Received: 12 September 2014; accepted: 15 January 2015; published online: 05 February 2015.

Citation: Schoelynck J, Puijalon S, Meire P and Struyf E (2015) Thigmomorphogenetic responses of an aquatic macrophyte to hydrodynamic stress. Front. Plant Sci. 6:43. doi: $10.3389 / \mathrm{fpls} .2015 .00043$

This article was submitted to Plant Physiology, a section of the journal Frontiers in Plant Science.

Copyright (C) 2015 Schoelynck, Puijalon, Meire and Struyf. This is an open-access article distributed under the terms of the Creative Commons Attribution License (CC BY). The use, distribution or reproduction in other forums is permitted, provided the original author(s) or licensor are credited and that the original publication in this journal is cited, in accordance with accepted academic practice. No use, distribution or reproduction is permitted which does not comply with these terms. 